\title{
Assessment of Effect of Note Taking on the Test Performance of Nursing Students in Selected Schools of Nursing
}

\author{
Ndie E.C, Eze A O \\ Department of Nursing Science, \\ Ebonyi State University, Abakalili
}

\begin{abstract}
This study aimed at determining the effect of note taking in the test performance of student nurses was conducted in two schools of nursing selected one each from Enugu and Ebonyi State of Nigeria. An experimental research design was used. 32 students in their second year were selected using random sampling from each of the schools that were also selected randomly from the two states. The schools were School of Nursing, Enugu State University Teaching Hospital, Enugu and School of Nursing, Mater Mesiricodea Hospital Afikpo Ebonyi State. A training package on note taking was constructed followed by an evaluation pre-test and post-test construction. The experiment was conducted in three steps of pre-test to both groups, execution of the teaching package to the experimental only and then a post-test to both groups. The results show that there is no significant difference $(p<0.05)(t=3.207, p=0.0 o 2)$ between the note taking method group and the control group. It was concluded that note taking as a method of learning may help the student to recall learnt material but may not give the student an added advantage in the test performance. So the student should lay emphasis on the study material more than note taking as a study method.
\end{abstract}

Keywords: Note taking, Academic performance, Student nurses, study method

\section{INTRODUCTION}

Academic performance is how students accomplish different tasks given to them and their ability to remember first and being also to communicate the knowledge verbally or in writing (Olomie 2010 and Joyful 2010). Academic performance is the index used to determine how well educational objectives have been achieved. Education has been seen as the process of helping an individual to discover, develop and make use of his inner ability, potentials and capabilities for successful living in society. In this process, it is academic performance of individual that is used to infer academic success or failure (Seidler, 2007).

The prime place of good study habit on academic performance among students cannot be underestimated. Note is the students closest companion. It is the most readily available core to the memory in the educational enterprise. Note taking is an integral part of the learning process that converts the art of reading to the art of studying. It is a means of achieving recall, reconstruction and utilization of learnt materials (Rimumu and Master 2006, Colemon 2003, and Nweze 2004).

Anyaegbunam (2001) described note taking as a memory aid, which assists one to compare what he has from a reading material. The approach does not describe the nature of note taking and how not to use notes. Note taking is a very important means by which students learn from texts. It is the process of jotting down excellent points while reading to develop memory, (Beveridae 2005).

A good study habits eliminates disjointed presentation of owner's unnecessary use of illustration, irrelevant answers and inability to get the required answers. Good study habit positively correlated with free recall (Onyenoku 2004 and Divesta and Gray 2002). Over the years, it is observed that the percentage of students that fail in the Nursing and Midwifery Council Examination is on the increase (N\&MCN 2014). Since it has been shown that poor study habit often lead to inadequate learning which subsequently lead to poor academic performance and no study in nursing has investigated the effect of note taking study methods on the academic performance of student nurses in Nigeria. This study therefore is designed to determine whether note taking has influence on students' test performance. 


\section{MeTHODOLOGY}

An experimental research design was used to compare the academic performance of the two groups that consist of note taking group, and the control group.

Two schools of Nursing were purposively selected and the school of Nursing Mater Mesiricodea Hospital Afikpo, Ebonyi State.

32 students were randomly selected from each 312 students from UNTH and 165 students in Mater hospital. The allocation of the schools into experimental groups was through balloting. 32 students from ESUTH were used as experimental group I (Note-taking).

32 students from Mater served as control group. Permissions were obtained from the school principals for their students to participate in the study. Each of the students gave their concert and willingly participated. The instrument for data collection was a fifty test questions constructed by the researchers on the personal and environmental hygiene. It comprised of multiple choice questions, fill in questions and true or false questions. The blue print questions served as pre-test and post-test instrument.

Training package was Note taking package and the note taking technique involved survey, question, read, reflect and review formula.

The reliability of the instrument was determined using a test-retest method from the result of pilot study conducted in school of Nursing in Abia State. The two scores were correlated using Pearson moment correlation that was found to be 0.745 .

The experimental procedure was done in three steps:

Step I: This is the pre-treatment assessment (pre-test) of all, the subjects in the two groups from where pre-test scores were generated.

Step II: Execution of the teaching sessions on Note taking for the experimental group only. They were taught techniques for Note taking using standardized teaching techniques.

Step III: Post treatment assessment (post-test) involving all the subjects in the two groups from where post-test scores were derived after the experimental manipulations.

The data obtained were analyzed to determine the difference between the mean of pre-test and posttest scores of the experiment categories using the analysis of covariance (ANCOVA). The null hypothesis tested at 0.05 level of significance is: There is no significance in the academic performance of students who are exposed to note taking study method and those in the control group.

\section{RESUltS}

Table 1. $t$-test analysis of pre-test score of the Note taking and control group.

\begin{tabular}{|c|c|c|c|c|c|c|c|c|}
\hline \multirow{3}{*}{$\begin{array}{l}\text { Variable } \\
\text { Pre-test } \\
\text { score }\end{array}$} & \multicolumn{8}{|c|}{ Note taking method } \\
\hline & $\mathrm{N}$ & $\bar{X}$ & $\mathrm{SD}$ & $\mathrm{N}$ & $\bar{X}$ & SD & $\mathrm{T}$ & $\mathrm{P}$ \\
\hline & 32 & 58.4650 & 8.003 & 32 & 55.3750 & 9.81359 & 0.131 & 0.001 \\
\hline
\end{tabular}

The result t-test analysis of the pre-test is shown on table 1 above. The result indicated a no significant difference $(\mathrm{P}<0.05)$ in the pre-test score of the two groups. This shows that the two groups were equal before the experimental manipulation.

Table II. Multiple t-test analysis of the adjusted post-test score for the student in note taking group and control group.

\begin{tabular}{|c|c|c|c|c|c|c|c|c|}
\hline Variable & \multicolumn{8}{|c|}{ Note taking method } \\
\hline $\begin{array}{l}\text { Pre-test } \\
\text { score }\end{array}$ & $\mathrm{N}$ & $\overline{\mathrm{X}}$ & SD & $\mathrm{N}$ & $\bar{X}$ & SD & $\mathrm{T}$ & $\mathrm{P}$ \\
\hline & 32 & 65.667 & 8.0030 & 32 & 59.6040 & 9.81359 & 3.207 & 0.003 \\
\hline
\end{tabular}

The adjusted post-test scores t-test of the note taking method and control is shown on Table II. The result shows that there is no significance difference $(\mathrm{P}<0.05)(\mathrm{t}=3.207, \mathrm{P}=0002)$ between the note taking method and the control group. 


\section{DISCUSSION}

The test performance of students who are exposed to note taking study method and those of the control group are statistically the same. This is in line with Diversta and Gray (2002) that concluded that once the student perceive the need for a good test performance, the student is likely to perform well irrespective of the study method chosen. This result do not rule out the importance of note taking method in learning process and as means of achieving recall, reconstruction of learnt materials as highlighted by Rimium and Master 2006, Coleman 2003 and Nweze 2005. Test performances are influenced by other variables. Note taking is just a memory aid to the reading materials according to Anyaegbunani.

It can then be concluded from the study that Note taking may help the student to recall learnt material but may not give the student an added advantage in the test performance. Teachers should encourage students to use different study methods like note taking, memorizing, group discussion or any other method that they find useful in learning.

It can then be recommended that students should be encouraged lay emphasis to the study materials more than the taking of notes as a study method.

\section{REFERENCES}

Joyful, J (2010) what is meant by academic performance. Wiki answers, anwer.com

Olamie, E.O (2010) what is meant by academic performance? Wiki answers, answers.com

Seidler, U and Sadkers T. (2007), principles of Educational psychological measurement and evaluation; sixth edition, Califonia, woods worth publishing.

Remum, A and Master, B (2006) Imagery and verbal processes. Reinehard and Winston press, New York.

Coleman, ND (2003), The Influence of the new port way curriculum on Harvard medical students. Academic Medicine journal

Nweze, P.U (2004) "philosophy of Nigerian in modern time, Nigeria", Etukokwa publishers.

Anyaegbunam, O.C (2001), An experimental study of the relationship between note taking practices and listening comprehension of college freshmen during expository lecture. Unpublished Doctoral Thesis, O.A.U Ile-Ife, pp 46-52.

Beveridae, C (2005), Human Association memory, Attitude towards mathematics; Journal of college science teaching; 15 pp 38-44

Onyenoka S.B (2004) A critical assessment of note taking strategies of students in polytechnic" English language studies in Nigeria Higher Education; British Council Freeman \& Co Ibadan, Nigeria.

Diverta, F, and Gray E (2002) "listening and taking Note". Journal of Educational psychology 10 page 22-28

N\&MCN (2014) Eliminated students from Nursing and Midwifery council qualifying examination. Examination workshop, Ibadan 